\title{
In-situ Remediation of Carbofuran-Contaminated Soil by Immobilized White-Rot Fungi
}

\author{
Zhaoxing Li", Xin Wang ${ }^{1 *}$, Zijun $\mathrm{Ni}^{1}$, Jia Bao ${ }^{1}$, Huiwen Zhang ${ }^{2}$ \\ ${ }^{1}$ School of Science, Shenyang University of Technology, Shenyang, China \\ ${ }^{2}$ Institute of Applied Ecology, Chinese Academy of Sciences, Shenyang, China
}

Received: 12 October 2018

Accepted: 6 January 2019

\begin{abstract}
The widespread use of carbofuran in agriculture and concomitant pollution of soil has caused health issues in virtue of its toxic effect and residue. Most bacteria degrade carbofuran incompletely, as phenolic metabolites are unable to break down. White-rot fungi are potent degraders of carbofuran owing to their extracellular ligninolytic enzyme systems. Here we studied the catabolism of carbofuran by Phlebia sp. (C strain), Lenzites betulinus (Y strain), and IIrpex lacteus (W strain). Corn stover, wheat straw, peanut shells, wood chips, and corn cobs were supplied as carriers to immobilize strains. The results showed that Phlebia.sp and Iopex lacteus were fit for the degradation of strains while corn stover and wheat straw are suitable as carriers. The strains grew better on the carrier at $28^{\circ} \mathrm{C}$ under acidic conditions. The degradation rate of carbofuran was up to $69.83 \%$ after Iopex lacteus within 5 days by corn stover. The orthogonal experiment proved that temperature and $\mathrm{pH}$ primarily affected degradation rate.
\end{abstract}

Keywords: in-situ remediation, carbofuran, soil, immobilized, white rot fungi

\section{Introduction}

Carbofuran (2,3-dihydro-2,2-dimethyl-7-benzofuranyl methylcarbamate) is a common and efficient carbamate pesticide that has been used as insecticide and acaricide [1-3]. It is used extensively for the control of pests, for example white grubs, corn rootworm, and mosquitoes $[4,5]$. Carbofuran has instant reaction against both nymphs and adults, killing them within $20 \mathrm{~min}$ [6]. However, it has strong toxicity, does great harm to the environment, and becomes a serious problem in environmental protection. In soil, carbofuran is very persistent with a half-life of about 110 days [7]. Air, soil,

*e-mail: wangxin110870@sut.edu.cn and food containing carbofuran have become a serious problem because of adverse impacts that pose threats not only to humans, but also animals, wildlife, and fish $[8,9]$. With strong contact and stomach toxicity, the compound can inhibit the production of cholinesterase [10-12]. Even worse, the process of the combination with cholinesterase is irreversible. Recent surveys suggest that carbofuran has significant negative influence on the liver and kidney functions and on certain blood parameters $[13,14]$. As a result, it is important to find a proper way to remove carbofuran in the environment.

Different approaches were used to degrade carbofuran in soil, for example photodegradation [15], adsorption [16,17], bioremediation [18,19], solid-phase extraction (SPE), and solid-phase microextraction (SPME) [20]. In recent years, immobilized technology has been applied to this field, with the advantage 
of high-capacity organisms and strong tolerance to adverse environments [21, 22]. Immobilization is defined as limiting the mobility of the microbial cells or their enzymes with a simultaneous preservation of their viability and catalytic functions [23-26]. The immobilized technology not only improves the activity of microbes, but also realizes the recycling of microbes $[27,28]$. Adsorption is one of the most common methods of immobilization [29, 30]. It is through the action of electrostatic, surface tension and adhesion between the charged microorganism cell and the carrier to make the microorganism immobilized on the surface and inside of the carrier and form the biofilm. The most obvious advantage of adsorption is that the operation is simple and easy to operate [31]. At the same time, because of the mild reaction condition, it will not cause the mutated inactivation of the microorganism. The materials of the carrier have the following characteristics: inexpensive and available, simple preparation and high mechanical strength [21].

White-rot fungi are efficient in degradation of recalcitrant compounds like xenobiotics and lignin by their extracellular ligninolytic enzyme system [32, 33]. Compared with bacteria, white-rot fungi have a distinctive superiority. The ligninolytic enzyme system comprises lignin peroxidase (LiP), Mn-dependent peroxidase (MnP), and laccase. The extracellular degradation system is activated by its own $\mathrm{H}_{2} \mathrm{O}_{2}$, triggering a series of free radical chain reactions by the enzyme to achieve no specific oxidative degradation of the substrate [34]. Recent studies have shown that immobilized technology can promote the growth and production of enzymes and produce enzymes in advance [35]. White-rot fungi do not need to precondition to particular pollutants, i.e., they can degrade certain low concentration substances in the environment to a level that is not detected. Moreover, they produce $\mathrm{OH}$ free radicals to change the $\mathrm{pH}$ value of the environment, which antagonizes the invasion of microbes.

The objectives of this study were to: 1) select the most suitable degrading strain and optimum carrier of white-rot fung, 2) reveal the factors affecting the process of degradation, and 3) evaluate the efficiency of the immobilized white-rot fungi applications on the soil remediation for carbofuran contaminations.

\section{Materials and Methods}

\section{Reagents}

The specific white-rot fungi were domesticated and trained in the Shenyang Institute of Applied Ecology, Chinese Academy of Sciences (Shenyang, China). The testing soil, free from pollution, were obtained from Shenyang University of Technology. Carbofuran (purity of $98 \%$ ) used in the experiment was purchased from Zhenjiang Jiansu Pesticide Chemical Company L.T.D (Zhenjiang, China).

\section{Activation of Strains}

The strain was inoculated into a solid agar medium in which malt extract powder was used as a nitrogen source for the cellulose decomposing microorganisms to grow, and fostered in an incubator at $28^{\circ} \mathrm{C}$ for $72 \mathrm{~h}$. White-rot fungi was transferred to a new solid medium of the same ingredient when it spread all over the agar plates. The operations above were repeated 3 times.

\section{Immobilization Procedure}

The carrier materials in the experiment contain wheat straw, corn stover, corn cob, wood chip, and peanut shells, which were cut into $3 \mathrm{~mm}$ pieces. $1 \mathrm{~g}$ carrier materials were placed into $10 \mathrm{ml}$ distilled water and heated at $121^{\circ} \mathrm{C}, 1.01325 \times 10^{5} \mathrm{~Pa}$ in high pressure steam sterilizer pot for $30 \mathrm{~min}$. After activation, accurately weighted strains of the same size were put with carriers under aseptic conditions. Then whiterot fungi was fostered in an incubator sealing with breathable films.

\section{Selecting Suitable Degrading Strain}

White-rot fungi were cultured at their best growth situation $\left(30^{\circ} \mathrm{C}\right.$, slightly acidic conditions) after being linked to carriers. Then the contaminated soil was degraded by different strains and carriers (Table 1) in order to obtain suitable degrading strain and degrading time.

\section{Preparing Carbofuran-Contaminated Soil}

$1.0 \mathrm{~g}$ carbofuran was accurately measured and dissolved in $500 \mathrm{ml}$ water in a conical flask by ultrasound. A $15 \mathrm{ml}$ sample was poured into the beaker containing $300 \mathrm{~g}$ soil and stirred by glass rods to make the water and soil mix evenly. The mass concentration of carbofuran was $100 \mathrm{mg} / \mathrm{kg}$.

Table 1. Treatment of experimental design.

\begin{tabular}{|c|c|}
\hline No. & Materials \\
\hline S1 & Blank \\
\hline S2 & Wheat straw \\
\hline S3 & Corn stover \\
\hline S4 & Wheat straw+Immobilized C strain \\
\hline S5 & Wheat straw+Immobilized Y strain \\
\hline S6 & Wheat straw+Immobilized W strain \\
\hline S7 & Corn stover+Immobilized C strain \\
\hline S8 & Corn stover+Immobilized Y strain \\
\hline S9 & Corn stover+Immobilized W strain \\
\hline
\end{tabular}


Table 2. Factor level of immobilized white rot fungi degradation; four factors: A: initial concentration $(\mathrm{mg} / \mathrm{kg})$; B: temperature $\left({ }^{\circ} \mathrm{C}\right)$; $\mathrm{C}$ : $\mathrm{pH}$ value; $\mathrm{D}$ : dosage of white rot fungi $(\mathrm{g})$, same as below table.

\begin{tabular}{|c|c|c|c|c|}
\hline Factor level & A & B & C & D \\
\hline 1 & 80 & 25 & 6 & 0.8 \\
\hline 2 & 100 & 30 & 7 & 1.0 \\
\hline 3 & 120 & 35 & 8 & 1.2 \\
\hline
\end{tabular}

\section{Degradation of Carbofuran by White-Rot Fungi}

$30 \mathrm{~g}$ soil was taken into a culture vessel after drying, and then $1.0 \mathrm{~g}$ immobilized white rot fungus was added. The degradation condition was set to $30^{\circ} \mathrm{C}$ and neutral $\mathrm{pH}$. The degradation rates of carbofuran were determined every $8 \mathrm{~h}$.

In the first group of experiments, the influence of a single factor on degradation rate was discussed. A total of four elements were contained: initial concentration of carbofuran, $\mathrm{pH}$ value, temperature and dosage of white rot fungi. Each experiment changed one factor. The initial concentrations of carbofuran were $60,80,100$, 120 and $200(\mathrm{mg} / \mathrm{kg})$. $\mathrm{pH}$ of soils were 5, 6, 7, 8 and 9 . The temperatures of incubators were 15, 20, 25, 30 and $35^{\circ} \mathrm{C}$. The dosages of white rot fungi were $0.4,0.8,1.0$, 1.5 and $2.0 \mathrm{~g}$, respectively.

In the orthogonal experiment, each factor was given three factor levels in Table 2. High degradation rates were achieved under these levels according to the single-factor experiment. Based upon Taguchi's $\mathrm{L}_{9}\left(3^{4}\right)$ fractional orthogonal array, four factor levels were combined as experiment plan, which are shown in Table 3.

\section{Sample Pretreatment}

$1 \mathrm{~g}$ soil was placed in a centrifuge tube and immersed with $10 \mathrm{ml}$ dichloromethane solution. Then

Table 3. Orthogonal analysis of immobilized white rot fungi degradation factors.

\begin{tabular}{|c|c|}
\hline No. & factor \& level \\
\hline 1 & $\mathrm{~A}_{1} \mathrm{~B}_{1} \mathrm{C}_{1} \mathrm{D}_{1}$ \\
\hline 2 & $\mathrm{~A}_{1} \mathrm{~B}_{2} \mathrm{C}_{2} \mathrm{D}_{2}$ \\
\hline 3 & $\mathrm{~A}_{1} \mathrm{~B}_{3} \mathrm{C}_{3} \mathrm{D}_{3}$ \\
\hline 4 & $\mathrm{~A}_{2} \mathrm{~B}_{1} \mathrm{C}_{2} \mathrm{D}_{3}$ \\
\hline 5 & $\mathrm{~A}_{2} \mathrm{~B}_{2} \mathrm{C}_{3} \mathrm{D}_{1}$ \\
\hline 6 & $\mathrm{~A}_{2} \mathrm{~B}_{3} \mathrm{C}_{1} \mathrm{D}_{2}$ \\
\hline 7 & $\mathrm{~A}_{3} \mathrm{~B}_{1} \mathrm{C}_{3} \mathrm{D}_{2}$ \\
\hline 8 & $\mathrm{~A}_{3} \mathrm{~B}_{2} \mathrm{C}_{1} \mathrm{D}_{3}$ \\
\hline 9 & $\mathrm{~A}_{3} \mathrm{~B}_{3} \mathrm{C}_{2} \mathrm{D}_{1}$ \\
\hline
\end{tabular}

the solution had an intermittent ultrasonic water bath at low temperature for $2 \mathrm{~h}$ and was centrifuged for $5 \mathrm{~min}$ at $4500 \mathrm{r} / \mathrm{min}$ in a refrigerated centrifuge. The upper extract liquid was transferred to a petri plate and methanol was added to $10 \mathrm{ml}$ after evaporation. At the end, the mixed solution was into an HPLC sampling bottle through a syringe of organic microporous membrane in $0.5 \mathrm{ml}$ volume for carbofuran measurement.

\section{HPLC Conditions}

The mobile phase was prepared with methyl alcohol and distilled water (55:45 volume ratio). An alkyl silica gel column was used. The UV wavelength was set to $280 \mathrm{~nm}$ at room temperature. The sample size was $10 \mu \mathrm{L}$ at a rate of $1.0 \mathrm{ml} / \mathrm{min}$ and the retention time was $10 \mathrm{~min}$.

\section{Data Processing}

Microsoft Excel software was used to process all the experimental data. SPSS Statistics 22.0 (SPSS Inc., Chicago, IL, USA) was used for statistical analysis, and $p<0.05$ was considered as a significant difference.

\section{Results and Discussion}

\section{Selection of Immobilized Carriers and Degrading Strains}

\section{Selection of Immobilized Carriers}

Strain $\mathrm{C}, \mathrm{Y}$ and $\mathrm{W}$ in different carriers were put into an incubator at $30^{\circ} \mathrm{C}$ for 20 days. Strains did not grow in the wood chip and grew poorly in the peanut shell and corn cob. In the wheat straw and corn stover, strains developed rapidly. Therefore, wheat straw and corn stover were selected as carriers in the next experiment.

According to the result, not every material is suitable for immobilization. Different support materials affect the result of strain growth. The adsorption capacity of various carriers is different, which lead to the difference of the amount of cells fixed. Some adsorption carriers may be toxic to microbial cells. The binding degree between various carriers and microbial cells is different, and some cells are easy to fall off.

\section{Selection of Degrading Strains}

Fig. 1 compared the degradation of carbofuran by immobilized white-rot fungi, blank carriers and carbofuran blank. The immobilized $\mathrm{C}$ and $\mathrm{W}$ strains had better degradation efficiency than Y strain. The curve rose rapidly in the first 5 days and then slowed down after 5 days of incubation. A small amount of carbofuran can be absorbed by two carrier materials as well as in illumination. The degradation rates were $66.35 \%, 55.46 \%$, and $65.48 \%$ with $\mathrm{C}$, $\mathrm{Y}$, and $\mathrm{W}$ strains 


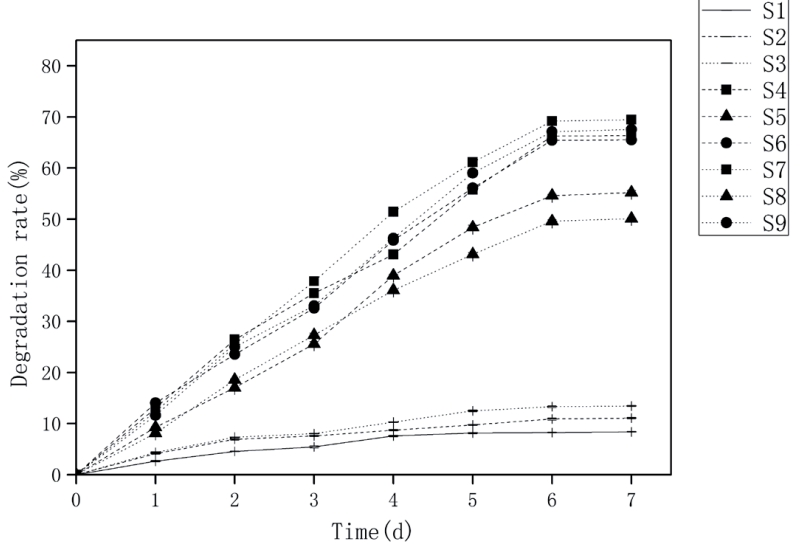

Fig. 1. Influence of immobilized strains on degradation of carbofuran.

by wheat straw and $69.14 \%, 49.86 \%$ and $67.12 \%$ by corn stover, respectively. The blank wheat straw was $11.14 \%$, blank corn stover $13.47 \%$, carbofuran blank $8.35 \%$. As a result, immobilized $\mathrm{C}$ and $\mathrm{W}$ strains were selected to degrade carbofuran in the single factor experiment, while corn stover was chosen as the carrier in the orthogonal experiment.

\section{Factors Affecting Carbofuran Degradation}

\section{Influence of Initial Concentration on the Degradation Rate of Carbofuran}

As in Fig. 2, immobilized white-rot fungi have good degradation effect of carbofuran under five concentration conditions. However, different strains and carrier materials obviously result in discrepant $(p<0.05)$. At first, the degradation ability increased with the rising concentration. The degradation rate reached

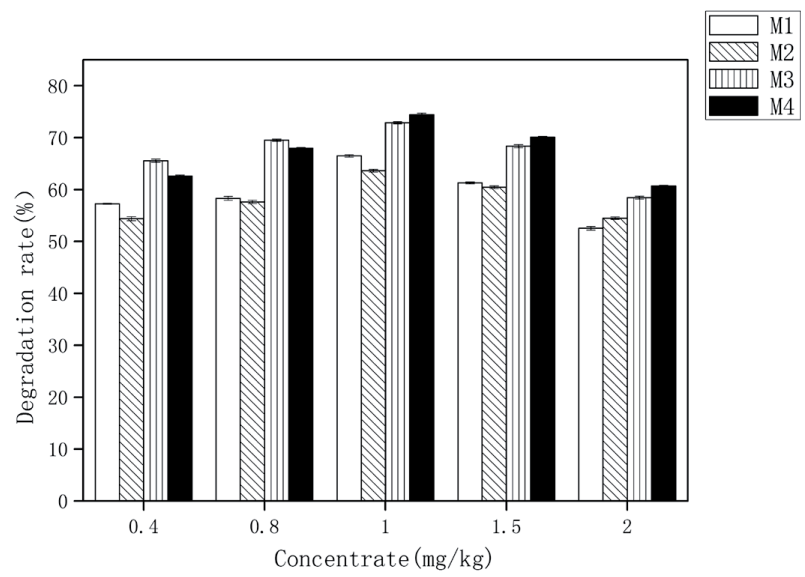

Fig. 2. Influence of initial concentration on immobilized strains degradation of carbofuran, M1: selected wheat straw+Immobilized C strain, M2: wheat straw+Immobilized W strain, M3: corn stover+Immobilized C strain, M4: corn stover+Immobilized W strain, same as below figure.

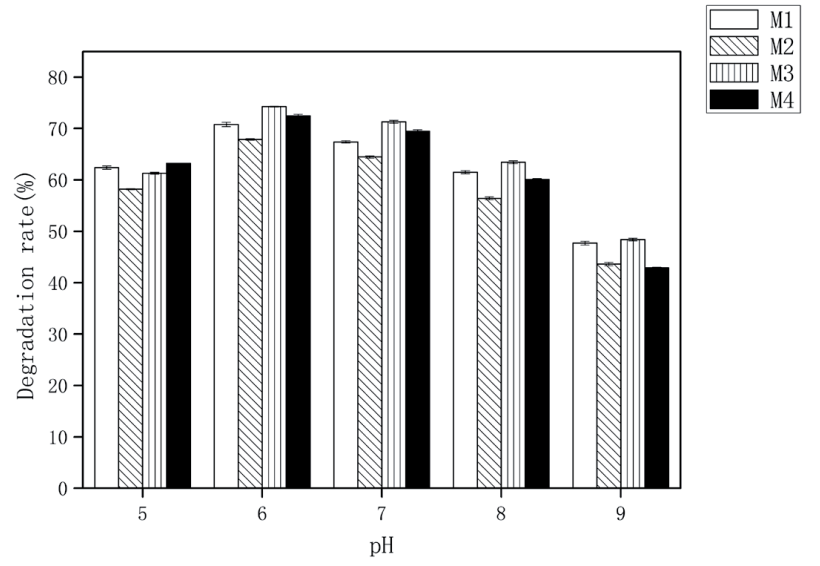

Fig. 3. Influence of $\mathrm{pH}$ value on immobilized strains degradation of carbofuran.

its maximum at initial carbofuran concentration of $100 \mathrm{mg} / \mathrm{kg}$. When the initial concentration was up to $120 \mathrm{mg} / \mathrm{kg}$, the degradation rate of the pollutants had a slight decline as well as significantly decreasing at $200 \mathrm{mg} / \mathrm{kg}$. This would be ascribable to the fact that a high concentration of carbofuran could inhibit the metabolism of white-rot fungi to a certain extent.

Therefore, the $100 \mathrm{mg} / \mathrm{kg}$ soil was the best initial concentration for remediation of carbofurancontaminated soil in this experiment. The degradation rates were $66.42 \%$ and $60.38 \%$, with $\mathrm{C}$ and $\mathrm{W}$ strains by wheat straw as well as $72.84 \%$ and $74.35 \%$ by corn stover, respectively.

\section{Influence of pH on the Degradation Rate of Carbofuran}

The results of degradation rates affected by $\mathrm{pH}$ are shown in Fig. 3. Based on statistical analysis, the influence of $\mathrm{pH}$ on $\mathrm{C}$ and $\mathrm{W}$ strains had significant differences $(p<0.05)$. More than $50 \%$ of carbofuran was removed in different $\mathrm{pH}$ conditions. The degradation

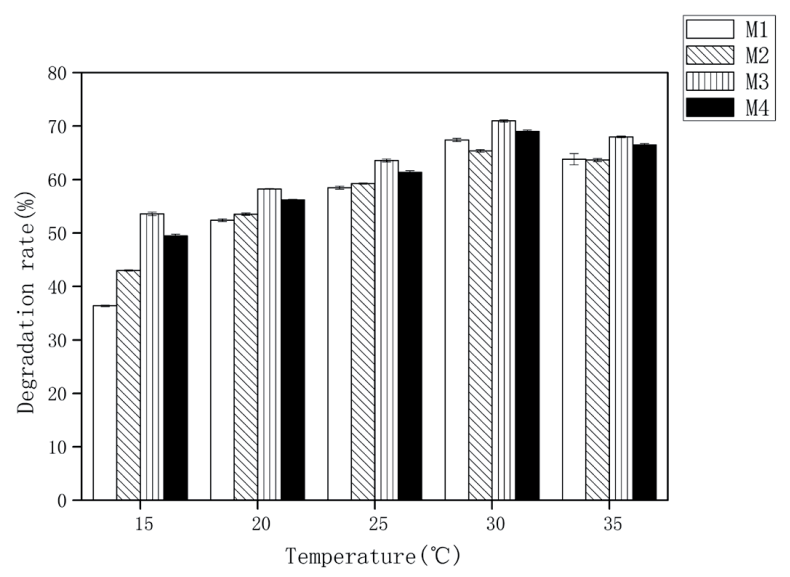

Fig. 4. Influence of temperature on immobilized strains degradation of carbofuran. 


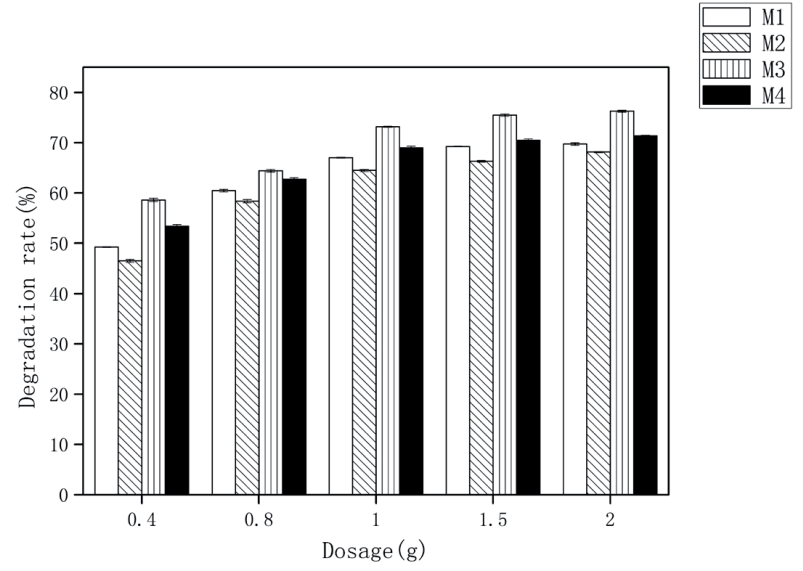

Fig. 5. Influence of dosage on immobilized strains degradation of carbofuran.

rates of $\mathrm{pH}=6$ was the highest as the secretion process of ligninolytic enzymes was promoted in a slight acidic environment. The degradation rates were up to $70.84 \%$ and $67.92 \%$ with $\mathrm{C}$ and $\mathrm{Y}$ strains by wheat straw and $74.39 \%$ and $72.42 \%$ by corn stover, respectively.

\section{Influence of Temperature on Carbofuran Degradation Rate}

After immobilization, white-rot fungi could adapt to higher temperature than before, so immobilized strains would be applied in a more broad temperature range than free strains. As shown in Fig. 4, the degradation rates were low at $15^{\circ} \mathrm{C}$ and $20^{\circ} \mathrm{C}$, which may be related to the fact that the growth of white-rot fungi was restricted and produced secondary metabolites at low temperatures. The degradation rate was highest at $30^{\circ} \mathrm{C}$, in accordance with optimum growth temperature of white-rot fungi. The result indicated that temperature had a major influence on the production of laccase in secondary metabolism of white-rot fungi $(p<0.05)$. At $30^{\circ} \mathrm{C}$, the degradation rates were $67.39 \%$ and $65.28 \%$

Table 4. Test results of orthogonal experiment.

\begin{tabular}{|c|c|}
\hline No. & Degradation rate \\
\hline 1 & $55.31 \%$ \\
\hline 2 & $67.43 \%$ \\
\hline 3 & $59.84 \%$ \\
\hline 4 & $53.56 \%$ \\
\hline 5 & $57.19 \%$ \\
\hline 6 & $68.32 \%$ \\
\hline 7 & $49.65 \%$ \\
\hline 8 & $66.32 \%$ \\
\hline 9 & $61.29 \%$ \\
\hline
\end{tabular}

with $\mathrm{C}$ and $\mathrm{Y}$ strains by wheat straw as well as $70.92 \%$ and $68.94 \%$ by corn stover, respectively.

\section{Influence of Dosage on the Degradation Rate of Carbofuran}

The influence of the dosage of white-rot fungi on the degradation rate of carbofuran was shown in Fig. 5. The degradation effect was enhanced significantly with increasing dosage $(p<0.05)$. When the dosage was set to $1.0 \mathrm{~g}$, the degradation effect improved little due to the limitation of carbofuran degradation in soil by white-rot fungi. The best initial dosage was set to $1.0 \mathrm{~g}$ and the degradation rates were $67.14 \%$ and $64.61 \%$ with $\mathrm{C}$ and $\mathrm{Y}$ strains by wheat straw, as well as $73.28 \%$ and $69.17 \%$ by corn stover, respectively.

\section{Analysis of the Orthogonal Experimental Results}

According to test results of orthogonal experiment (Table 4), the efficiency of immobilized strain was the highest (68.32\%) in the 6th experiment and lowest $(49.65 \%)$ in the $7^{\text {th }}$ experiment. As in Table 5, the temperature was the key factor to degrade carbofuran, $\mathrm{pH}$ was the important factor, and dosage and initial concentrate were the general factor.

Catalytic efficiency was affected by each parameter as below. The degradation ability of strains was the best at $30^{\circ} \mathrm{C}$, followed by $35^{\circ} \mathrm{C}$ and $25^{\circ} \mathrm{C}$. The increasing order of degradation rate was $\mathrm{pH} 8<\mathrm{pH} 7<\mathrm{pH} 6$. The optimum initial carbofuran concentration was $120 \mathrm{mg} / \mathrm{kg}$, and the next ones were $100 \mathrm{mg} / \mathrm{kg}$ and $80 \mathrm{mg} / \mathrm{kg}$. The activity of strains was significantly highest when the dosage of white-rot fungi was $1.0 \mathrm{~g}$ than that of $1.2 \mathrm{~g}$ and $0.8 \mathrm{~g}$.

Above all, the optimum condition to degrade carbofuran was as follows: initial concentration of carbofuran $-80 \mathrm{mg} / \mathrm{kg}$, temperature $-30^{\circ} \mathrm{C}, \mathrm{pH} 6$ and dosage of white-rot fungi $-1.0 \mathrm{~g}$, the combination of $A_{1} B_{2} C_{1} D_{2}$. However, this condition was not included in the orthogonal experiment plan. Another experiment was performed according to the combination and the degradation rates were up to $71.69 \%$.

Table 5. Analysis of carbofuran degradation orthogonal experimental results, $k_{1}, k_{2}$ and $k_{3}$ are the average of each experiment result for certain factor at level 1,2 and 3; $R$ are the extreme deviation of $k$ for certain factors.

\begin{tabular}{|c|c|c|c|c|}
\hline Factor & $\mathrm{A}$ & $\mathrm{B}$ & $\mathrm{C}$ & $\mathrm{D}$ \\
\hline$k_{1}$ & 60.86 & 52.84 & 63.32 & 57.93 \\
\hline$k_{2}$ & 59.69 & 63.65 & 60.76 & 61.80 \\
\hline$k_{3}$ & 59.09 & 63.15 & 55.56 & 59.91 \\
\hline$R$ & 1.77 & 10.81 & 7.76 & 3.87 \\
\hline
\end{tabular}




\section{Conclusions}

In this study, wheat straw and corn stover were selected as carriers of immobilized white-rot fungi. $\mathrm{C}$ and $\mathrm{W}$ strains were effective on carbofuran within 5 days and the highest degradation rate reached $69.14 \%$ and $67.12 \%$, respectively. The appropriate degradation conditions included the initial concentration of $100 \sim 200 \mathrm{mg} / \mathrm{L}, \mathrm{pH}$ of $6 \sim 8$ and temperature of $25 \sim 35^{\circ} \mathrm{C}$. Subsequent orthogonal experiments illustrated that reaction temperature and $\mathrm{pH}$ value had a bigger impact on degradation effect than initial carbofuran concentration and dosage of white-rot fungi. The best situation was the initial concentration of $80 \mathrm{mg} / \mathrm{kg}, \mathrm{pH}$ of 6 , temperature of $30^{\circ} \mathrm{C}$, and dosage of white-rot fungi of $1.0 \mathrm{~g}$. The data acquired from the experiment could be used for future research on pesticide degradation.

\section{Acknowledgements}

This research is funded by the National Nature Science Foundation of China (No. 31670515) and the National Key R\&D Program of China (No. 2017YFD0800702).

\section{Conflict of Interest}

None of the authors have any conflicts of interest to declare.

\section{References}

1. BENITEZ F.J., ACERO J.L., REAL F.J. Degradation of carbofuran by using ozone, UV radiation and advanced oxidation processes. J. Hazard. Mater. 89 (1), 51, 2002.

2. ONUNGA D.O., KOWINO I.O., NGIGI A.N., OSOGO A., ORATA F., GETENGA Z.M., WERE H. Biodegradation of carbofuran in soils within Nzoia River Basin, Kenya. J. Environ. Sci. Heal. B. 50, 387, 2015.

3. HOSSEN M.S., TANVIR E.M., PRINCE M.B., PAUL S., SAHA M., ALI M.Y., GAN S.H., KHALIL M.I., KARIM N. Protective mechanism of turmeric (Curcuma longa) on carbofuran-induced hematological and hepatic toxicities in a rat model. Pharm. Biol. 55 (1), 1937, 2017.

4. BANO N., MUSARRAT J. Characterization of a novel carbofuran degrading Pseudomonas sp. with collateral biocontrol and plant growth promoting potential. FEMS Microbiol. Lett. 231, 13, 2004.

5. ANEESH E.M., VIJAYAN V.A. Laboratory selection of carbofuran tolerant line of Culex Quinquefasciatus say, the filarial vector at Mysore. J. Commun. Dis. 42 (3), 201, 2010.

6. OTIENO P.O., LALAH J.O., VIRANI M., JONDIKO I.O., SCHRAMM K. Carbofuran and its toxic metabolites provide forensic evidence for furadan exposure in vultures (Gyps africanus) in Kenya. Bull. Environ. Contam. Toxicol. 84, 536, 2010.

7. NGUYEN T.P.O., HELBLING D.E., BERS K., FIDA T.T., WATTIEZ R., KOHLER H.-P. E., SPRINGAEL D., DE
MOT R. Genetic and metabolic analysis of the carbofuran catabolic pathway in Novosphingobium sp. KN65.2. Appl. Microbiol. Biotechnol. 98, 8235, 2014.

8. DE SIQUEIRA A., SALVAGNI F.A., YOSHIDA A.S., GONCALVES-JUNIOR V., CALEFI A.S., FUKUSHIMA A.R., SPINOSA H.D.S., MAIORKA P.C. Poisoning of cats and dogs by the carbamate pesticides aldicarb and carbofuran. Res. Vet. Sci. 102, 142, 2015.

9. RUIZ-SUÁREZ N., BOADA L.D., HENRÍQUEZHERNÁNDEZ L.A., GONZÁLEZ-MOREO F., SUÁREZPÉREZ A., CAMACHO M., ZUMBADO M., ALMEIDAGONZÁLEZ M., DEL MAR TRAVIESO-AJA M., LUZARDO O.P. Continued implication of the banned pesticides carbofuran and aldicarb in the poisoning of domestic and wild animals of the Canary Islands (Spain). Sci. Total. Environ. 505, 1093, 2015.

10. BRETAUD S., SANGLIO P., SALIGAUT C., AUPERIN B. Biochemical and behavioral effects of carbofuran in gold fish (Carassius auratus). Environ. Toxicol. Chem. 21, 175, 2002

11. OSTEN R.J., ARANA O.A., GUILHERMINO L., SOARES A.M.V.M. In vivo evaluation of three biomarkers in the mosquito fish (Gambusia yaucatana) exposed to pesticides. Chemosphere 58 (5), 627, 2005.

12. BEGUM G. Assessment of biochemical markers of carbofuran toxicity and recovery response in tissues of the freshwater teleost, Clarias Batrachus (Linn). Bull. Environ. Contam. Toxicol. 81 (5), 480, 2008.

13. ISLAM M.S., MOHANTA M.K., SAHA A.K., MONDOL A., HOQUE M.M., ROY A.K. Carbofuran-induced alterations in body morphometrics and histopathology of liver and kidneys in the Swiss albino mice Mus Musculus L. International Journal of Scientific Research in Environmental Sciences. 2(9), 308, 2014.

14. OJHA A., GUPTA Y. Evaluation of genotoxic potential of commonly used organophosphate pesticides in peripheral blood lymphocytes of rats. Hum. Exp. Toxicol. 34 (4), 390, 2015.

15. ATIFI A., TALIPOV M., MOUNTACER H., RYAN M.D., SARAKHA M. A density functional theory and laser flash photolysis investigation of carbofuran photodegradation in aqueous medium. J. Photochem. Photobiol. A. Chem. 235, $1,2012$.

16. MEMON G.Z., BHANGER M.I., AKHTAR M. The removal efficiency of chestnut shells for selected pesticides from aqueous solutions. J. Colloid. Interface. Sci. 315(1), 33, 2007.

17. KRISHNA K.R., PHILIP L. Adsorption and desorption characteristics of lindane, carbofuran and methyl parathion on various Indian soils. J. Hazard. Mater. 160, 559,2008

18. BERMÚDEZ-COUSO A., FERNÁNDEZ-CALVIÑO D., RODRÍGUEZ-SALGADO I., NÓVOA-MUÑOZ J.C., ARIAS-ESTÉVEZ M. Comparison of batch, stirred flow chamber, and column experiments to study adsorption, desorption and transport of carbofuran within two acidic soils. Chemosphere 88 (1), 106, 2012.

19. PIMMATA P., REUNGSANG A., PLANGKLANG P. Comparative bioremediation of carbofuran contaminated soil by natural attenuation, bioaugmentation and biostimulation. Int. Biodeterior. Biodegradation. 85, 196, 2013.

20. LÓPEZ-BLANCO M.C., CANCHO-GRANDE B., SIMAL-GÁNDARA J. Comparison of solid-phase extraction and solid-phase, microextraction for carbofuran in water analyzed by high performance 
liquid chromatography-photodiode-array detection. J. Chromatogr. A. 963, 117, 2002.

21. DZIONEK A., WOJCIESZYŃSKA D., GUZIK U. Natural carriers in bioremediation: A review. Electron. J. Biotechnol. 23, 28, 2016.

22. WANG X., LIU L., YAO M.Q., ZHANG H.W., BAO J. Degradation of carbofuran in contaminated soil by immobilized laccase. Pol. J. Environ. Stud. 26 (3), 1, 2017.

23. KOURKOUTAS Y., BEKATOROU A., BANAT I.M., MARCHANT R., KOUTINAS A.A. Immobilization technologies and support materials suitable in alcohol beverages production: A review. Food Microbiol. 21 (4), 377, 2004.

24. WOJCIESZYŃSKA D., HUPERT-KOCUREK K., JANKOWSKA A., GUZIK U. Properties of catechol 2,3-dioxygenase from crude extract of Stenotrophomonas maltophilia strain KB2 immobilized in calcium alginate hydrogels. Biochem. Eng. J. 66, 1, 2012.

25. GUZIK U., HUPERT-KOCUREK K., KRYSIAK M., WOJCIESZYŃSKA D. Degradation potential of protocatechuate 3,4-dioxygenase from crude extract of Stenotrophomonas maltophilia strain KB2 immobilized in calcium alginate hydrogels and on glyoxyl agarose. Biomed. Res. Int. 2014, 1, 2014.

26. GUZIK U., HUPERT-KOCUREK K., WOJCIESZYŃSKA D. Immobilization as a strategy for improving enzyme properties - Application to oxidoreductases. Molecules. 19, 8995, 2014.

27. COHEN Y. Biofiltration - the treatment of fluids by microorganisms immobilized into the filter bedding material: a review. Bioresour. Technol. 77 (3), 257, 2001.
28. ZHOU L.C., LI G.Y., AN T.C., FU J.M., SHENG G.Y. Recent patents on immobilized microorganism technology and its engineering application in wastewater treatment. Recent Patents on Engineering. 2, 28, 2008.

29. JESIONOWSKI T., ZDARTA J., KRAJEWSKA B. Enzyme immobilization by adsorption: a review. Adsorption. 20, 801, 2014.

30. SUGAHARA V.H., VARÉA G.D.S. Immobilization of Beauveria bassiana lipase on silica gel by physical adsorption. Braz. Arch. Biol. Technol. 57 (6), 842, 2014.

31. WU J.C., LEE S.S., MAHMOOD M.M.B., CHOW Y., TAKUKDER M.M.R., CHOI W.J. Enhanced activity and stability of immobilized lipases by treatment with polar solvents prior to lyophilization. J. Mol. Catal. B-Enzym. 45, 108, 2007.

32. BRODKORB T.S., LEGGE R.L. Enhanced biodegradation of phenanthrene in oil tar contaminated soils supplemented with Phanerochaete chrysosporium. Appl. Environ. Microbiol. 58 (9), 3117, 1992.

33. HEINFLING A., BERGBAUER M., SZEWYK U. Biodegradation of azo and phthalocyanine dyes by Trametes versicolor and Bjerkandera adusta. Appl. Microbiol. Biotechnol. 48 (2), 261, 1997.

34. WANG F. Study on white-rot fungi degradation and adsorption of carbon tetrachloride and trichloroethylene. China University of Geosciences, China, 2016.

35. WU H.J. The situ remediation of pesticide contaminated soil by immobilized white-rot fungi. Shenyang University of Technology, China, 2016. 
